DOI: https://doi.org/10.24127/ajpm.v8i3.2261

\title{
MINAT, KEMANDIRIAN DAN HASIL BELAJAR MAHASISWA PENDIDIKAN MATEMATIKA DALAM E-LEARNING BERBASIS EDMODO
}

\author{
Ahmad Hatip ${ }^{1}$, Yuni Listiana ${ }^{2}$ \\ ${ }^{1,2}$ Pendidikan Matematika, Universitas Dr Soetomo \\ E-mail: $\quad \frac{\text { ahmad.hatip@unitomo.ac.id }{ }^{l)}}{2)}$
}

Received 4 September 2019; Received in revised form 30 November 2019; Accepted 28 December 2019

\begin{abstract}
Abstrak
E-learning adalah suatu kemajuan penting dalam system pendidikan modern. E-learning ini membawa pengaruh terjadinya proses transformasi pendidikan konvensional ke dalam bentuk digital, baik secara isi (contents) maupun sistemnya. E-learning menawarkan pembelajaran menggunakan media elektronik yang dapat mendukung pembelajaran menjadi lebih menarik, efektif dan efisisen. Dalam penelitian ini kami mengkaji tentang pengaruh pembelajaran e-learning berbasis Edmodo terhadap minat belajar mahasiswa, kemandirian belajar mahasiswa, dan hasil belajar mahasiswa. Jenis penelitian termasuk dalam kategori kuantitatif eksplanasi eksperimen, dengan metode analisis data kuantitatif dengan SPSS. Dari hasil penelitian didapatkan bahwa e-learning berbasis edmodo berpengaruh terhadap minat belajar mahasiswa, kemandirian belajar mahasiswa, dan hasil belajar mahasiswa dengan nilai signifikan masing masing adalah 61.24, 61.84, dan 76.52. Selain itu juga didapat bahwa ada korelasi positif antara minat belajar terhadap hasil belajar dalam e-learning berbasis edmodo dan kemandirian belajar terhadap hasil belajar dalam e-learning berbasis edmodo, sedangkan untuk minat belajar terhadap kemandirian belajar dalam e-learning berbasis edmodo tidak menunjukkan adanya pengaruh apapun.
\end{abstract}

Kata kunci: E-learning; edmodo; hasil belajar; kemandirian belajar; minat belajar.

\begin{abstract}
E-learning is an important advance in the modern education system. E-learning transforms conventional education into digital form, both in terms of contents and the systems. E-learning offers learning using electronic media that can support learning to be more interesting, effective and efficient. In this paper we study the influence of Edmodo-based e-learning on student learning. This research belongs to the quantitative category of experimental explanations, with quantitative data analysis methods with SPSS. The results of this study found that edmodo-based e-learning had an effect on student learning interest, student learning independence, and student learning outcomes with significant values are 61.24, 61.84, and 76.52 respectively. In addition, we are also found that there was a positive correlation between learning interest towards learning outcomes and learning independence towards learning outcomes in edmodo-based e-learning, while there is no any influence between learning interest towards learning independence in edmodo-based e-learning.
\end{abstract}

Keywords: E-learning, Edmodo; independence of learning; interest to learn; Learning outcomes.

\section{PENDAHULUAN}

Kegiatan merupakan suatu kegiatan transfer pesan dari pendidik ke peserta didik. Dalam hal ini, pesan yang disampaikan tidak selalu harus bertatap muka namun juga bisa dilakukan secara jarak jauh melalui bantuan suatu media perantara.
Dalam perkembangannya, akhir - akhir ini sistem pendidikan dibenturkan dengan tantangan baru di era revolusi industri 4.0 dengan input pendidikan, terutama pendidikan tinggi, adalah generasi $\mathrm{Z}$ dengan aktivitas serba digital. Pada era ini, informasi dapat diakses dengan sangat mudah dan cepat tanpa 
terbatas waktu dan tempat melalui sebuah piranti telepon pintar atau smartphone dan laptop dengan dukungan koneksi internet.

Menyongsong era industri 4.0 dimana generasi muda dibenturkan dengan masa digitalisasi yang memudahkan akses informasi secara terbuka dan luas, maka secara aktif kegiatan pembelajaran di perguruan tinggi harus disesuaikan untuk mengakomodasi kebutuhan mahasiswa yang tumbuh di jaman milenial. Sehingga maraknya penggunaan media sosial pada era ini memberikan tantangan baru dalam dunia pembelajaran untuk menciptakan proses pembelajaran yang dekat dengan aktivitas peserta didik di media sosial. Salah satu platform online yang menyediakan layanan pembelajaran secara online dengan mengadaptasi aktivitas pengguna di media sosial adalah Edmodo.

Edmodo adalah platform yang dirintis oleh Nicolas Brogdan Jeff O'Hara pada akhir tahun 2008 yang memungkinkan adanya interaksi antar pengguna yang berperan sebagai guru dan siswa. Sehingga dapat dikatakan bahwa Edmodo lahir ketika smartphone mulai mendominasi aktivitas hampir setiap orang.

Edmodo sangat komprehensif sebagai sebuah course management system seperti layaknya Moodle, dengan tampilan antar muka (interface) yang menyerupai facebook yang merupakan media sosial popular saat ini, penguna tidak akan merasa asing bahkan akan merasa mudah untuk menggunakannya (Pradnyana, Pradnyana, \& Sindu, 2016).

Mahasiswa yang sebagian besar tergolong dalam kelompok remaja sebenarnya sangat adaptif dalam merespon perkembangan teknologi dan informasi. Hal ini ditunjukkan dengan data yang diperoleh Kemkominfo pada tahun 2014 pengguna internet di Indonesia mencapai 82 juta dan $80 \%$ penggunanya adalah remaja. Kendala yang seringkali dihadapi dalam pembelajaran adalah kurangnya kemandirian dalam proses pembelajaran, antara lain adalah masih mendominasinya penggunaan metode ceramah, pembelajaran yang masih terpusat pada pendidik (teacher centered learning), serta kurangnya pengoptimalan penggunaan jaringan internet dalam pembelajaran padahal mahasiswa memiliki keterampilan dalam mengoperasikan komputer. Mata kuliah Linear Programming merupakan matakuliah teori yang materinya lebih banyak berisi soal cerita atau masalah kontekstual, penggunaan metode ekspositori akan membuat pembelajaran menjadi bosan dan lama. Akibatnya, mahasiswa masih sangat bergantung pada dosen dan minat serta motivasi belajar mereka pun kurang karena tidak ada variasi pembelajaran. Oleh karena itu, diperlukan solusi untuk mengatasi masalah tersebut. Salah satu alternatif yang dapat digunakan untuk meningkatkan kemandirian dalam proses pembelajaran adalah dengan implementasi e-learning. Karakteristik e-learning yang memungkinkan mahasiswa tidak lagi bergantung pada dosen tetapi dapat belajar dari berbagai sumber, sehingga diharapkan kemandirian belajar mahasiswa akan meningkat. Selain itu e-learning juga dapat dijadikan sebagai sumber bahan ajar yang interaktif dan menarik, sehingga minat, motivasi, kemandirian dan hasil belajar mahasiswa diharapkan dapat meningkat.

Pada Tahun 2013, Basori memulai penelitian tentang pembelajaran menggunakan Edmodo yang berjudul "Pemanfaatan Social Learning Network 
DOI: https://doi.org/10.24127/ajpm.v8i3.2261

"Edmodo" dalam Membantu
Perkuliahan Teori Bodi Otomotif di
Prodi PTM JPTK FKIP UNS". Hasil
penelitian menunjukkan bahwa ada
peningkatan yang signifikan dalam kontribusi Edmodo dalam perkuliahan, dimana fitur Edmodo sangat mendukung manajemen pengajaran dan pembelajaran dengan tema Edmodo sangat user friendly, sehingga mudah digunakan. Selain itu, didapat hasil bahwa siswa merasakan tingkat kepuasan yang tinggi dengan layanan Edmodo (Basori, 2013). Hasil penelitian lain mengungkapkan bahwa dilihat dari manfaat dan juga fitur-fiturnya, edmodo merupakan pilihan yang sangat tepat digunakan sebagai media pembelajaran online bagi dosen dan mahasiswa, dimana orang tua/wali mahasiswa dapat memantau perkembangan aktifitas belajar putra-putri mereka (Bv, 2016). Senada dengan penelitian sebelumnya, berdasarkan penelitian oleh Aisiyah pada tahun 2017 didapat bahwa penggunaan e-learning berbasis Edmodo dalam suatu kelas mampu meningkatkan motivasi dan hasil belajar siswa dibandingkan dengan kelas yang tidak menggunakan Edmodo (Aisiyah, Dewi, \& Rahayu, 2017). Hasil penelitian lain juga menyebutkan proses pembelajaran e-learning berbasis edmodo pada mata kuliah Geometri membuat pembelajaran matematika lebih menarik dan interaktif bagi mahasiswa serta membuat pembelajaran di kelas menjadi tidak membosankan (Hadi \& Rulviana, 2018).

Fakta yang terjadi di kelas adalah mahasiswa cenderung mengalami kebosanan dengan model pembelajaran yang selama ini diterapkan di kelas. Meskipun dosen telah menggunakan slide power point sebagai media pembelajaran di kelas, mahasiswa cenderung hanya mengikuti penjelasan dosen tanpa ada inisatif untuk belajar mandiri baik secara individu maupun kelompok. Mahasiswa hanya menunggu penjelasan dosen dan mengerjakan tugas ketika ada perintah. Hasil belajar mahasiswa masih di bawah kriteria bagus sehingga perlu remedial yang berulang untuk memperbaiki hasil belajar mahasiswa. solusi yang diharapkan adalah adanya kreativitas pembelajaran yang mampu mengakomodasi kebutuhan mahasiswa.

Berdasarkan beberapa hasil penelitian terdahulu, kami akan mengkaji tentang pengaruh pembelajaran e-learning berbasis Edmodo terhadap minat belajar mahasiswa, kemandirian belajar mahasiswa, dan hasil belajar mahasiswa dalam e-learning berbasis edmodo. Serta keterkaitan antara setiap variabel satu dengan variabel lainnya. Dalam kasus ini, terdapat 3 jenis variabel yang saling berkaitan tersebut adalah minat belajar, kemandirian belajar mahasiswa, dan hasil belajar mahasiswa. Tujuan yang diharapkan dari hasil penelitian ini adalah adanya perubahan minat, kemandirian, dan hasil belajar mahasiswa dengan menggunakan $e$ learning berbasis edmodo.

\section{METODE PENELITIAN}

Jenis penelitian ini adalah kuantitatif eksplanasi eksperimen. Penelitian kuantitatif eksplanasi eksperimen umumnya menggunakan sampel penelitian untuk dilakukan generalisasi terhadap populasi. Menurut (Sugiyono, 2010), penelitian eksplanasi adalah penelitian yang digunakan untuk menjelaskan kedudukan-kedudukan dari variabelvariabel yang di teliti serta hubungan antara satu variabel dengan variabel lainnya. 
DOI: https://doi.org/10.24127/ajpm.v8i3.2261

Populasi penelitian ini adalah mahasiswa Pendidikan Matematika semester 1-8. Adapun sampel penelitian secara purposif sampling yaitu kelas Pendidikan Matematika Kelas A dan Kelas K semester 4 dan 6 di Tahun Akademik Genap 2017-2018 berjumlah 30 mahasiswa.

Metode pengumpulan data yang digunakan antara lain metode dokumentasi, angket, dan tes. Metode dokumentasi digunakan untuk memperoleh data mengenai jumlah dan nama-nama mahasiswa subyek penelitian. Metode angket digunakan untuk mengetahui minat dan kemandirian belajar mahasiswa sebelum dan sesudah pembelajaran dilakukan. Metode tes digunakan untuk mengetahui hasil belajar mahasiswa. Metode angket juga digunakan untuk mengetahui tanggapan mahasiswa terhadap pembelajaran yang telah berlangsung. Selain itu, angket digunakan untuk perbaikan pembelajaran e-learning berbasis edmodo. Angket dikembangkan dalam format isian tertutup menggunakan skala Likert 1-4 yang dianalisis deskriptif melalui jumlah skor dilanjutkan analisis statistik.

Instrumen yang digunakan dalam penelitian ini yaitu lembar angket dan lembar tes. Desain yang digunakan dalam penelitian ini adalah Post-test Only Control Group Design, yaitu dengan melihat perbedaan minat, kemandirian dan hasil belajar mahasiswa sesudah perlakuan antara kelompok eksperimen dan kelompok kontrol.

Secara garis besar teknik analisis data yang digunakan dalam penelitian ini terbagi enam, yaitu :

1. Membuktikan hipotesis pertama digunakan teknik analisis data statistik independent sample t-test dengan desain penelitian sebagaimana Tabel 1 .

Tabel 1. Desain penelitian minat belajar.

\begin{tabular}{clcc}
\hline Kelas tindakan & Tindakan 1 & Tindakan 2 & Tindakan 3 \\
\hline Eksperimen & Awal & E-learning berbasis Edmodo & Angket \\
Kontrol & Awal & Pembelajaran Ekspositori & Angket \\
\hline
\end{tabular}

Keterangan:

$$
\begin{aligned}
& \mathrm{E}=\text { kelompok eksperimen } \quad \mathrm{O}=\text { minat belajar sesudah perlakuan } \\
& \mathrm{K}=\text { kelompok kontrol }
\end{aligned}
$$

2. Membuktikan hipotesis kedua dengan desain penelitian digunakan teknik analisis data statistik independent sample t-test sebagaimana Tabel 2.

Tabel 2. Desain penelitian kemandirian belajar.

\begin{tabular}{clcc}
\hline Kelas tindakan & Tindakan 1 & Tindakan 2 & Tindakan 3 \\
\hline Eksperimen & Awal & E-learning berbasis Edmodo & Angket \\
Kontrol & Awal & Pembelajaran Ekspositori & Angket \\
\hline
\end{tabular}

Keterangan:

$$
\begin{aligned}
& \mathrm{E}=\text { kelompok eksperimen } \\
& \mathrm{K}=\text { kelompok kontrol }
\end{aligned}
$$


DOI: https://doi.org/10.24127/ajpm.v8i3.2261

3. Membuktikan hipotesis ketiga digunakan teknik analisis data statistik independent sample t-test dengan desain penelitian sebagaimana Tabel 3.

Tabel 3. Desain penelitian hasil belajar.

\begin{tabular}{clcc}
\hline Kelas tindakan & Tindakan 1 & Tindakan 2 & Tindakan 3 \\
\hline Eksperimen & Awal & E-learning berbasis Edmodo & Tes \\
Kontrol & Awal & Pembelajaran Ekspositori & Tes \\
\hline
\end{tabular}

Keterangan:

$$
\begin{aligned}
& \mathrm{E}=\text { kelompok eksperimen } \quad \mathrm{O}=\text { tes sesudah perlakuan } \\
& \mathrm{K}=\text { kelompok kontrol }
\end{aligned}
$$

4. Membuktikan hipotesis ketiga digunakan teknik analisis data statistik uji regresi antara minat belajar dengan hasil belajar.

\section{HASIL PENELITIAN DAN PEMBAHASAN}

Uji Perbedaan Dua Means Data

5. Membuktikan hipotesis ketiga digunakan teknik analisis data statistik uji regresi antara kemandirian belajar dengan hasil belajar.

6. Membuktikan hipotesis ketiga digunakan teknik analisis data statistik uji regresi antara minat belajar dengan kemandirian belajar.

Minat Siswa antara yang Menggunakan E-learning Berbasis Edomodo dengan yang Tanpa Edmodo

Sebelum diuji, dilakukan uji prasyarat yaitu uji normalitas dan uji homogenitas. Data berdistribusi normal dan homogen. Hasil uji perbedaan dua means data minat siswa antara yang menggunakan e-learning berbasis edomodo dengan yang tanpa edmodo pada Tabel 4.

Tabel 4. Hasil uji independent sample test minat mahasiswa

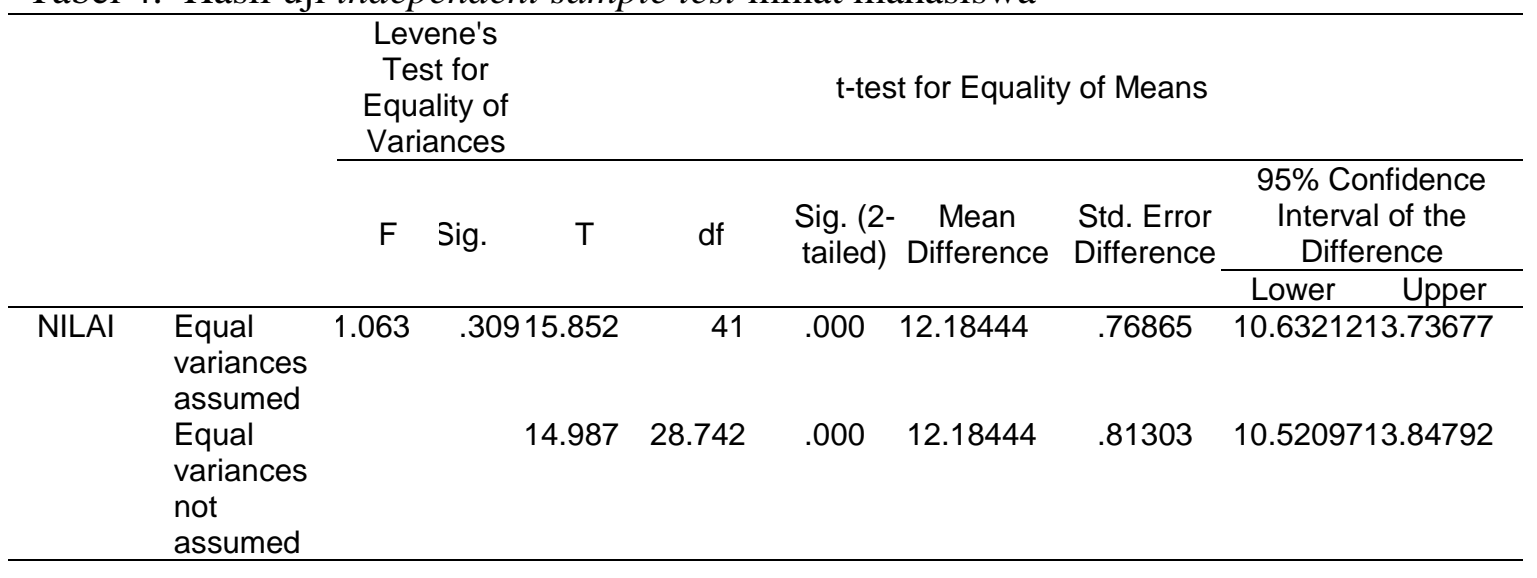

Berdasarkan Tabel 4 diperoleh besarnya probabilitas 0.000 dengan 
DOI: https://doi.org/10.24127/ajpm.v8i3.2261

demikian probabilitas $0.000<0.05$ sehingga $\mathrm{H}_{1}$ diterima artinya ada perbedaa nminat belajar matematika mahasiswa dengan e-learning berbasis edmodo dan tanpa edmodo. Selain dari nilai signifikansi, terlihat bahwa rerata minat mahasiswa yang belajar dengan e-learning berbasis edmodo lebih tinggi yaitu 61,24 dibandingkan dengan mahasiswa yang belajar tanpa $e$ learning berbasis edmodo sebesar 49,05. Karena terdapat perbedaan antara minat belajar mahasiswa dalam penerapan e-learning berbasis edmodo dengan tanpa edmodo maka dapat disimpulkan bahwa terdapat pengaruh e-learning berbasis edmodo terhadap minat belajar mahasiswa program studi matematika Fakultas Keguruan dan Ilmu Pendidikan.

\section{Uji Perbedaan Dua Means Data Kemandirian Siswa antara yang Menggunakan E-learning Berbasis Edomodo dengan yang Tanpa Edmodo}

Sebelum diuji, dilakukan uji prasyarat yaitu uji normalitas dan uji homogenitas. Data berdistribusi normal dan homogen. Hasil Uji perbedaan dua means data kemandirian siswa antara yang menggunakan e-learning berbasis edomodo dengan yang tanpa edmodo ditunjukkan pada tabel 5 .

Berdasarkan Tabel 5 diperoleh besarnya probabilitas 0.002 dengan demikian probabilitas $0.002<0.05$ sehingga $\mathrm{H}_{1}$ diterima artinya ada perbedaan kemandirian belajar matematika mahasiswa dengan $e$ learning berbasis edmodo dan tanpa edmodo.Selain dari nilai signifikansi, terlihat bahwa rerata kemandirian mahasiswa yang belajar dengan $e$ learning berbasis edmodo lebih tinggi yaitu 61,84 dibandingkan dengan mahasiswa yang belajar tanpa $e$ learning berbasis edmodo sebesar 57,33. Karena terdapat perbedaan antara kemandirian belajar mahasiswa dalam penerapan e-learning berbasis edmodo dengan tanpa edmodo maka dapat disimpulkan bahwa terdapat pengaruh e-learning berbasis edmodo terhadap kemandirian belajar mahasiswa program studi matematika Fakultas Keguruan dan Ilmu Pendidikan.

Tabel 5. Hasil uji independent sample test kemandirian mahasiswa.

\begin{tabular}{|c|c|c|c|c|c|c|c|c|c|c|}
\hline & \multicolumn{2}{|c|}{$\begin{array}{l}\text { Levene's } \\
\text { Test for } \\
\text { Equality of } \\
\text { Variances } \\
\end{array}$} & \multicolumn{7}{|c|}{ t-test for Equality of Means } \\
\hline & & \multirow[t]{2}{*}{$\mathrm{F}$} & \multirow[t]{2}{*}{ Sig. } & \multirow[t]{2}{*}{ T } & \multirow[t]{2}{*}{ Df } & \multirow{2}{*}{$\begin{array}{l}\text { Sig. } \\
(2- \\
\text { tailed) }\end{array}$} & \multirow[t]{2}{*}{$\begin{array}{c}\text { Mean } \\
\text { Difference }\end{array}$} & \multirow{2}{*}{$\begin{array}{l}\text { Std. Error } \\
\text { Difference }\end{array}$} & \multicolumn{2}{|c|}{$\begin{array}{l}95 \% \text { Confidence } \\
\text { Interval of the } \\
\text { Difference }\end{array}$} \\
\hline & & & & & & & & & Lower & Upper \\
\hline \multirow[b]{2}{*}{ NILAI } & $\begin{array}{l}\text { Equal } \\
\text { variances } \\
\text { assumed }\end{array}$ & 1.357 & .251 & 3.310 & 41 & .002 & 4.50667 & 1.36150 & 1.75706 & 7.25627 \\
\hline & $\begin{array}{l}\text { Equal } \\
\text { variances } \\
\text { not } \\
\text { assumed }\end{array}$ & & & 3.513 & 40.948 & .001 & 4.50667 & 1.28291 & 1.91568 & 7.09766 \\
\hline
\end{tabular}


DOI: https://doi.org/10.24127/ajpm.v8i3.2261

\section{Uji Perbedaan Dua Means Data Hasil Belajar Siswa antara yang Menggunakan E-learning Berbasis Edomodo dengan yang Tanpa Edmodo}

Sebelum diuji, dilakukan uji prasyarat yaitu uji normalitas dan uji homogenitas. Data berdistribusi normal dan homogen. Hasil uji perbedaan dua means data hasil belajar siswa antara yang menggunakan e-learning berbasis edmodo dengan yang tanpa edmodo ditunjukkan pada Tabel 6.

Tabel 6. Hasil uji independent sample test hasil belajar mahasiswa

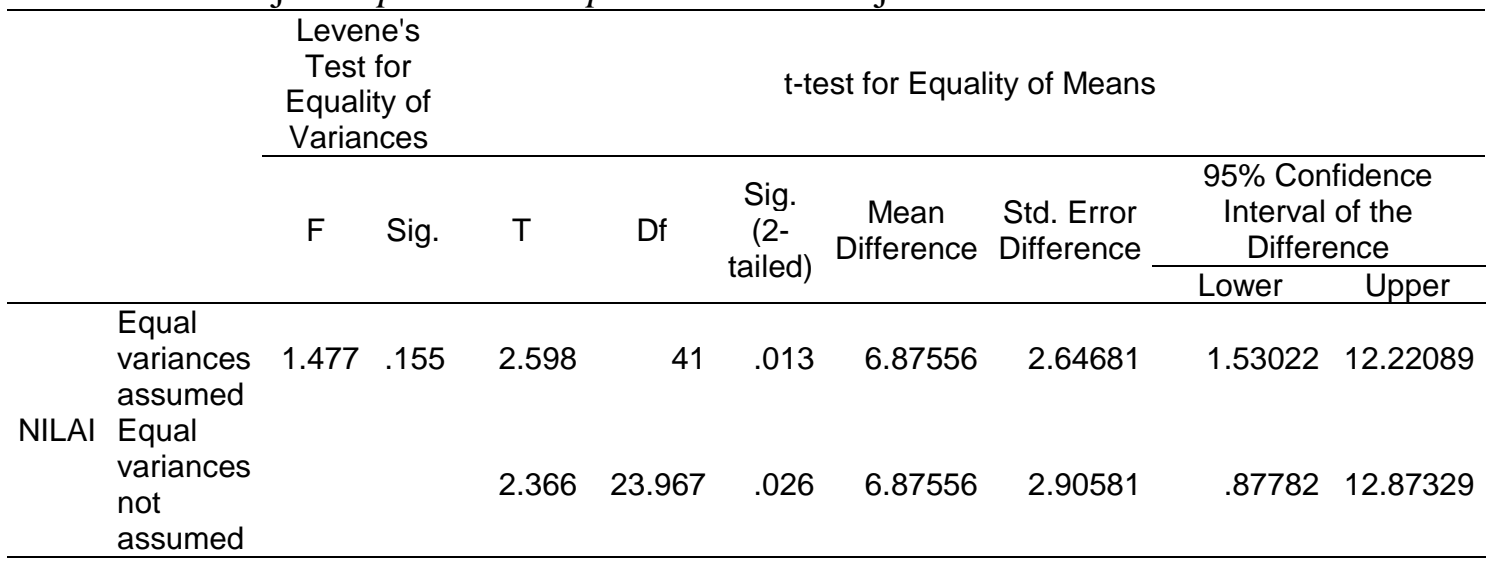

Berdsarkan Tabel 6 diperoleh besarnya probabilitas 0.013 dengan demikian probabilitas $0.013<0.05$ sehingga $\mathrm{H}_{1}$ diterima artinya ada perbedaan hasil belajar matematika mahasiswa dengan e-learning berbasis edmodo dan tanpa edmodo.Selain dari nilai signifikansi, terlihat bahwa rerata hasil belajar mahasiswa yang belajar dengan e-learning berbasis edmodo lebih tinggi yaitu 76,32 dibandingkan dengan mahasiswa yang belajar tanpa $e$ learning berbasis edmodo sebesar 69,44 . Karena terdapat perbedaan antara hasil belajar mahasiswa dalam penerapan e-learning berbasis edmodo dengan tanpa edmodo maka dapat disimpulkan bahwa terdapat pengaruh e-learning berbasis edmodo terhadap hasil belajar mahasiswa program studi matematika Fakultas Keguruan dan Ilmu Pendidikan.

\section{Pengaruh Minat terhadap Hasil Belajar}

Sebelum diuji, dilakukan uji prasyarat yaitu uji normalitas, uji homogenitas, dan uji linearitas. Hasil uji menunjukkan data berdistribusi normal, homogen, dan linear. Hasil uji pengaruh minta terhadap hasil belajar adalah sebagaimana dalam Tabel 7.

Tabel 7. Nilai koefisien determinasi minat terhadap hasil belajar mahasiswa.

\begin{tabular}{lrrrr}
\hline Model & R & R Square & Adjusted R Square & $\begin{array}{c}\text { Std. Error of the } \\
\text { Estimate }\end{array}$ \\
\hline 1 & $.627^{\mathrm{a}}$ & .393 & .366 & 4.76913 \\
\hline
\end{tabular}

a. Predictors: (Constant), minat

Berdasarkan Tabel 7, diketahui bahwa koefisien determinasi sebesar
0,366 yang bermakna bahwa sebesar $36,6 \%$ minat berpengaruh terhadap hasil 
DOI: https://doi.org/10.24127/ajpm.v8i3.2261

belajar mahasiswa dalam e-learning berbasis edmodo. Sisanya dipengaruhi oleh faktor lain.

Tabel 8. Hasil uji regresi minat terhadap hasil belajar mahasiswa.

\begin{tabular}{|c|c|c|c|c|c|c|}
\hline \multirow{3}{*}{ Model } & & \multicolumn{3}{|c|}{ Coefficients $^{\text {a }}$} & \multirow{3}{*}{$\mathrm{T}$} & \multirow{3}{*}{ Sig. } \\
\hline & & Unstandardizec & Coefficients & Standardized & & \\
\hline & & B & Std. Error & $\begin{array}{c}\text { Coefficients } \\
\text { Beta }\end{array}$ & & \\
\hline \multirow[b]{2}{*}{1} & (Constant) & -33.837 & 28.578 & & -1.184 & .248 \\
\hline & Minat & 1.799 & .466 & .627 & 3.857 & .001 \\
\hline
\end{tabular}

a. Dependent Variable: $y$

Berdasarkan Tabel 8 diperoleh besarnya probabilitas 0.001 dengan demikian probabilitas $0.001<0.05$ sehingga $\mathrm{H}_{1}$ diterima artinya ada pengaruh minat belajar terhadap hasil belajar mahasiswa dengan menggunakan e-learning berbasis edmodo.

\section{Pengaruh Kemandirian terhadap Hasil Belajar}

Sebelum diuji, dilakukan uji prasyarat yaitu uji normalitas, uji homogenitas, dan uji linearitas. Hasil uji menunjukkan data berdistribusi normal, homogen, dan linear. Hasil uji pengaruh kemandirian terhadap hasil belajar disajikan pada Tabel 9 .

Tabel 9. Nilai koefisien determinasi kemandirian terhadap hasil belajar mahasiswa.

\begin{tabular}{|c|c|}
\hline R Square & $\begin{array}{c}\text { Std. Error of the } \\
\text { Estimate }\end{array}$ \\
\hline $.433^{\mathrm{a}}$ & 5.51572 \\
\hline Predictors: (Constant), mandiri & \\
\hline $\begin{array}{l}\text { Berdasarkan Tabel 9, diketahui } \\
\text { ahwa koefisien determinasi sebesar } \\
152 \text { yang bermakna bahwa sebesar } \\
5,2 \% \text { kemandirian belajar berpengaruh } \\
\text { rhadap hasil belajar mahasiswa dalam } \\
\text { learning berbasis edmodo. Sisanya } \\
\text { ipengaruhi oleh faktor lain.Dari hasil }\end{array}$ & $\begin{array}{llr}\text { besarnya probabilitas } 0.031 & \text { dengan } \\
\text { demikian probabilitas } 0.031< & 0.05 \\
\text { sehingga } \mathrm{H}_{1} \text { diterima artinya ada } \\
\text { pengaruh kemandirian belajar terhadap } \\
\text { hasil belajar mahasiswa dengan } \\
\text { menggunakan e-learning berbasis } \\
\text { edmodo }\end{array}$ \\
\hline
\end{tabular}
output SPSS pada Tabel 10, diperoleh

Tabel 10. Hasil uji regresi kemandirian terhadap hasil belajar mahasiswa.

Coefficients $^{\mathrm{a}}$

\begin{tabular}{llrrrrr}
\hline Model & & \multicolumn{2}{c}{ Unstandardized Coefficients } & $\begin{array}{l}\text { Standardized } \\
\text { Coefficients } \\
\text { Beta }\end{array}$ & t & \multicolumn{1}{l}{ Sig. } \\
& & \multicolumn{1}{c}{ B } & Std. Error & \multicolumn{2}{c}{. } & \\
\hline \multirow{2}{*}{1} & (Constant) & 44.091 & 14.023 & & 3.144 & .005 \\
& Mandiri & .521 & .226 & .433 & 2.305 & .031 \\
\hline
\end{tabular}

a. Dependent Variable: $y$ 
DOI: https://doi.org/10.24127/ajpm.v8i3.2261

\section{Pengaruh Minat terhadap Kemandirian}

Sebelum diuji, dilakukan uji prasyarat yaitu uji normalitas, uji homogenitas, dan uji linearitas. Hasil uji menunjukkan data berdistribusi normal, homogen, dan linear. Hasil uji pengaruh minat terhadap kemandirian belajar disajikan pada Tabel 11 dan Tabel 12.

Tabel 11. Nilai koefisien determinasi minat terhadap kemandirian.

\begin{tabular}{lrrrr}
\hline Model & R & R Square & Adjusted R Square & $\begin{array}{c}\text { Std. Error of the } \\
\text { Estimate }\end{array}$ \\
\hline 1 & $.116^{\text {a }}$ & .014 & -.029 & 5.05317 \\
\hline
\end{tabular}

a. Predictors: (Constant), minat

Berdasarkan Tabel 11, diketahui bahwa koefisien determinasi sebesar 0,029 yang bermakna bahwa sebesar $02,9 \%$ minat belajar tidak berpengaruh terhadap kemandirian belajar mahasiswa dalam e-learning berbasis edmodo.

Tabel 12. Hasil uji regresi minat terhadap kemandirian mahasiswa.

Coefficients $^{\mathrm{a}}$

\begin{tabular}{|c|c|c|c|c|c|c|}
\hline \multirow[t]{2}{*}{ Model } & & \multicolumn{2}{|c|}{ Unstandardized Coefficients } & \multirow{2}{*}{$\begin{array}{l}\text { Standardized } \\
\text { Coefficients } \\
\text { Beta }\end{array}$} & \multirow[t]{2}{*}{$\mathrm{t}$} & \multirow[t]{2}{*}{ Sig. } \\
\hline & & B & Std. Error & & & \\
\hline \multirow[b]{2}{*}{1} & (Constant) & 78.849 & 30.280 & & 2.604 & .016 \\
\hline & Minat & -.278 & .494 & -.116 & -.562 & .580 \\
\hline
\end{tabular}

a. Dependent Variable: $y$

Dari hasil pada Tabel 12 diperoleh besarnya probabilitas 0.580 dengan demikian probabilitas $0.580>$ 0.05 sehingga $\mathrm{H}_{0}$ diterima artinya tidak ada pengaruh minat belajar terhadap kemandirian belajar mahasiswa dengan menggunakan e-learning berbasis edmodo.

Untuk mengetahui tingkat perbedaan minat mahasiswa, selain dari nilai signifikansi, terlihat bahwa rerata minat mahasiswa yang belajar dengan e-learning berbasis edmodo lebih tinggi yaitu 61.24 dibandingkan dengan mahasiswa yang belajar tanpa $e$ learning berbasis edmodo sebesar 49.05. Karena terdapat perbedaan antara minat belajar mahasiswa dalam penerapan e-learning berbasis edmodo dengan tanpa edmodo maka terdapat pengaruh e-learning berbasis edmodo terhadap minat belajar mahasiswa program studi matematika Fakultas Keguruan dan Ilmu Pendidikan.

Begitu juga dengan tingkat kemandirian, terlihat bahwa rerata kemandirian mahasiswa yang belajar dengan e-learning berbasis edmodo lebih tinggi yaitu 61.84 dibandingkan dengan mahasiswa yang belajar tanpa $e$ learning berbasis edmodo sebesar 57.33. Karena terdapat perbedaan antara kemandirian belajar mahasiswa dalam penerapan e-learning berbasis edmodo dengan tanpa edmodo maka terdapat pengaruh e-learning berbasis edmodo terhadap kemandirian belajar mahasiswa program studi matematika Fakultas Keguruan dan Ilmu Pendidikan.

Rerata hasil belajar mahasiswa yang belajar dengan e-learning berbasis edmodo lebih tinggi yaitu 76.32 dibandingkan dengan mahasiswa yang 
DOI: https://doi.org/10.24127/ajpm.v8i3.2261

belajar tanpa e-learning berbasis edmodo sebesar 69.44. Karena terdapat perbedaan antara hasil belajar mahasiswa dalam penerapan e-learning berbasis edmodo dengan tanpa edmodo maka terdapat pengaruh e-learning berbasis edmodo terhadap hasil belajar mahasiswa program studi matematika Fakultas Keguruan dan Ilmu Pendidikan.

Dari perhitungan diketahui bahwa koefisien determinasi minat terhadap hasil belajar mahasiswa sebesar 0.366 yang bermakna bahwa sebesar 36.6\% minat berpengaruh terhadap hasil belajar mahasiswa dalam e-learning berbasis edmodo. Sisanya dipengaruhi oleh faktor lain. Prosentase minat sebesar $36.6 \%$ dianggap sebagai efek yang besar. Hasil belajar banyak dipengaruhi oleh berbagai faktor, terutama dalam diri mahasiswa. dari $100 \%$ faktor yang berpengaruh terhadap keberhasilan belajar, 36.6\% mahasiswa berhasil belajarnya karena minat dari pembelajaran yang dilakukan secara elektronik. Hal ini tentunya harus menjadi patokan. Dengan penggunaan e-learning menjadikan minat mahasiswa lebih tinggi.

Dari perhitungan diketahui bahwa koefisien determinasi kemandirian belajar terhadap hasil belajar mahasiswa sebesar 0.152 yang bermakna bahwa sebesar $15.2 \%$ kemandirian belajar berpengaruh terhadap hasil belajar mahasiswa dalam e-learning berbasis edmodo. Sisanya dipengaruhi oleh faktor lain.

Hasil penelitian tentang pengaruh e-learning berbasis Edmodo terhadap minat dan kemandirian belajar selaras dengan penelitian yang dilakukan oleh (Nugraheni \& Dina, 2017) menyatakan bahwa terdapat perbedaan rerata hasil belajar mahasiswa yang diberi perlakuan e-learning dengan mahasiswa yang tidak diberikan perlakuan. Kelompok mahasiswa yang mendapat e-learning mempunyai rerata 3.67 sedangkan kelompok mahasiswa yang tanpa e-learning mempunyai rerata 3.48. Hasil penelitian lain yang dilakukan oleh (Supriani, 2017) menyatakan bahwa siswa yang menggunanakn e-learning dengan menggunakan Quipper School saat pembelajaran mendapatkan nilai yang lebih baik dibandingkan dengan siswa yang diajar dengan metode konvensional. Siswa juga memiliki efek yang positif dalam bidang kemandirian belajar khususnya pada materi bangun datar. Penelitian selanjutnya yang dilakukan oleh (Arifin \& Herman, 2018) menyatakan hasil bahwa pembelajaran yang menggunakan $e$ learning dengan model web centric course mempunyai pengaruh terhadap pemahaman konsep siswa dan kemandirian belajar matematika pada siswa Sekolah Dasar.

Penelitian tentang pengaruh $e$ learning terhadap hasil belajar selaras dengan penelitian yang dilakukan oleh (A'yun, Sujiwo, \& Hidayatullah, 2019) yang menyatakan bahwa terdapat pengaruh yang signifikan e-learning terhadap hasil belajar mahasiswa matematika. Penelitian lain yang menyatakan hasil yang sama adalah hasil penelitian oleh (Rahmatia, Monawati, \& Darnius, 2017) yang menyatakan bahwa ada pengaruh $e$ learning terhadap hasil belajar siswa di Banda Aceh pada materi pecahan. Penelitian berikutnya yang juga selaras adalah penelitian yang dilakukan oleh (Ibrahim \& Suardiman, 2014) yang menyatakan hasil bahwa terdapat pengaruh yang signifikan e-learning terhadap motivasi dan prestasi belajar. 


\section{KESIMPULAN DAN SARAN}

Berdasarkan hasil analisis disimpulkan bahwa terdapat pengaruh antara e-learning berbasis edmodo terhadap minat, kemandirian, dan hasil belajar mahasiswa matematika. Dari uji regresi juga ditemukan bahwa ada pengaruh antara minat belajar dan kemandirian belajar dengan hasil belajar matematika dalam e-learning berbasis edmodo pada mahasiswa matematika, namun tidak ditemukan pengaruh yang signifikan antara minat belajar dengan kemandirian belajar matematika dalam e-learning berbasis edmodo pada mahasiswa matematika.

Adapun saran yang dapat diberikan adalah diharapkan penelitian diharapkan untuk diadakan penelitian lanjutan pada materi lain atau aplikasi yang lain (selain edmodo) untuk mengetahui pengaruhnya dalam pembelajaran sehingga dapat digunakan sebagai pembanding.

\section{DAFTAR PUSTAKA}

Aisiyah, Y. D. P., Dewi, E. R. S., \& Rahayu, P. (2017). Penerapan ELearning Berbasis Edmodo pada Materi Sistem Koordinasi untuk Meningkatkan Motivasi dan Hasil Belajar Siswa. Seminar Nasional Sains dan Entrepreneurship IV Tahun 2017.

http://prosiding.upgris.ac.id/inde x.php/snse2017/snse2017/paper/ view/1805

Arifin, F., \& Herman, T. (2018). Pengaruh Pembelajaran ELearning Model Web Centric Course Terhadap Pemahaman Konsep dan Kemandirian Belajar Matematika Siswa. Jurnal Pendidikan Matematika, 12(2), $1-12$. https://doi.org/10.22342/jpm.12. 2.4152.1-12

A'yun, Q., Sujiwo, D. A. C., \& Hidayatullah, A. W. (2019). Pengaruh e-learning terhadap hasil belajar matematika pada mahasiswa teknik informatika. Justindo (Jurnal Sistem dan Teknologi Informasi Indonesia), 4(1), 27-35. https://doi.org/10.32528/justindo .v4i1.2420

Basori, B. (2013). Pemanfaatan social learning network "edmodo" dalam membantu perkuliahan teori bodi otomotif di prodi ptm jptk fkip uns. Jiptek: Jurnal Ilmiah Pendidikan Teknik dan Kejuruan, $\quad 6(2)$. https://doi.org/10.20961/jiptek.v 6i 2.12562

Bv, U. B. U. (2016). E-learning berbasis edmodo dalam pengajaran bahasa inggris pada jurusan akuntansi politeknik negeri samarinda. eksis, 12(1).

Hadi, F. R., \& Rulviana, V. (2018). Analisis proses pembelajaran elearning berbasis edmodo pada mata kuliah geometri. Jurnal bidang pendidikan dasar, 2(1), 63-68.

https://doi.org/10.21067/jbpd.v2 i1.2200

Ibrahim, D. S., \& Suardiman, S. P. (2014). Pengaruh Penggunaan E-Learning Terhadap Motivasi dan Prestasi Belajar Matematika Siswa SD Negeri Tahunan Yogyakarta. Jurnal prima edukasia, 2(1), 66-79. https://doi.org/10.21831/jpe.v2i1 .2645

Nugraheni, A. R. E., \& Dina, D. (2017). Pengaruh penerapan pembelajaran e-learning terhadap kemandirian dan minat 
DOI: https://doi.org/10.24127/ajpm.v8i3.2261

belajar mahasiswa pada mata
kuliah wawasan dan kajian
mipa. Edusains, $9(1)$.
https://doi.org/10.15408/es.v9i1.
5458

Pradnyana, G. A., Pradnyana, I. M. A., \& Sindu, I. G. P. (2016). Pelatihan penggunaan e-learning berbasis media sosial edmodo bagi guru SMA di kecamatan buleleng. Seminar nasional pengabdian kepada masyarakat, 1 . http://eproceeding.undiksha.ac.i d/index.php/senadimas/article/vi ew/254

Rahmatia, M., Monawati, M., \& Darnius, S. (2017). Pengaruh Media E-Learning Terhadap Hasil Belajar Matematika Siswa Kelas IV SDN 20 Banda Acehpengaruh Media ELearning Terhadap Hasil Belajar Matematika Siswa Kelas IV SDN 20 Banda Aceh. Jurnal Ilmiah Mahasiswa Pendidikan Guru Sekolah Dasar, 2(1).

Sugiyono. (2010). Metode penelitian pendidikan kuantitatif, kualitatif, dan $R \& D$. Bandung: alfabeta.

Supriani, Y. (2017). Menumbuhkan Kemandirian Belajar Matematika Siswa Berbantuan Quipper School. JIPMAT, 1(2). https://doi.org/10.26877/jipmat. v1i2.1248 